\title{
Successional structure and useful condition of mowing-and-grazing landscapes
}

\author{
Marina Ufimtseva ${ }^{1, *}$ and Alfia Khamidullina $^{1}$ \\ ${ }^{1}$ State Agrarian University of the Northern Trans-Urals, Russia
}

\begin{abstract}
The paper presents data on the indicators of livestock production, the number of farm animals and poultry in the Tyumen region. The characteristics and significance of near-village forage lands are given. The studied forage lands are assigned to the forest-steppe lowland latitudinal-zonal area of the Kurgan province and contain valuable species of herbs: Calamagrostis epigejos, Bromopsis inermis, Festuca pratensis, Vicia villosa Roth, Trifolium rubens L., Medicago falcata. The territory of pastures is used for mowing and grazing animals of the individual sector, which prevents sodding and degeneration and has a significant impact on the consistent regular change of the biological community (phytocoenosis, microbial community, etc.). The hay yield is $14.7 \mathrm{c} / \mathrm{ha}$, which corresponds to natural meadows without cultivation. To improve the quality of hay and yield, the authors suggest carrying out agrotechnical measures: compliance with the terms of mowing the grass - a week before flowering or at the beginning of flowering of meadow grasses; introduction of potash fertilizers, which will increase the content of grasses in the herbage and will reduce the specific weight of forbs; application of nitrogen fertilizer in a mixture with potash and complete mineral fertilization, which will reduce the level of forbs by almost half; undersowing of leguminous grasses.
\end{abstract}

\section{Introduction}

Last year in the Tyumen region, there were 264.3 thousand heads of cattle in farms of all categories, including cows - 109.0 thousand heads, pigs - 323.6 thousand heads, sheep and goats - 149.6 thousand heads, reindeer - 957.4 thousand heads, horses - 20.4 thousand heads, poultry $-10,043.1$ thousand heads. In farms of all categories, the production of meat (carcass weight) increased by $8.6 \%$, milk - by $4.4 \%$, insignificantly decreased egg production. On a per capita basis, the production of meat (carcass weight) was $35 \mathrm{~kg}$, milk $155 \mathrm{~kg}$, eggs - 425 pieces. In the farms of the rural population at the beginning of 2020 , there were 93.2 thousand heads of cattle (of which 36.2 thousand heads were cows), pigs 60.7 thousand heads, sheep and goats - 129 thousand heads. With the increase in agricultural production, the question of the fodder base of animals is acute and, of course, natural fodder lands - hayfields and pastures - play an important role here. Near-village hayfields and pastures (outside the rest regime and elements of rational organization of grazing) were and remain the main source of pasture fodder for animals of the individual

\footnotetext{
*Corresponding author: yfim@mail.ru
} 
(private) sector and peasant (farmer) households in many settlements [1]. Past land use reflects the current state of agro-pasture systems in the local community [2]. Grazing is a potentially useful management tool in pasture landscapes [3], since in hayfields and pastures, the content of soil organic matter and soil organic carbon was higher than in abandoned lands [4].

The aim of the study was to assess the successional structure and useful condition of mowing-and-grazing landscapes.

\section{Materials and Methods}

Field geobotanical survey was carried out using a detailed route method. When describing the vegetation, in accordance with the requirements of the methods generally accepted in phytocoenology, a test site with a size of $10 \mathrm{~m}^{2}$ was laid in the most characteristic place for the grouping. The description of the herbage was carried out according to the O. Drude scale. On the spot, a description of the vegetation was carried out - the species composition of the herbage, its projective cover, height, phase of development and useful condition.

In terms of physical and geographical zoning, the studied forage lands belong to the forest-steppe plain latitudinal-zonal region, the Kurgan province [5].

In terms of landscape, the territory is an alternation of elevated areas with meadow steppes, flat plains with birch and pine forests, meadows and swamps. Meadow steppes on leached chernozems occupy the right bank of the Tobol river and gently sloping high terraces of the Iset river. Pine grass forests, along clearings with birch trees, occupy the sandy terraces of Tobol, Emurtla and Iset rivers. Among the forests, there are small spots of sphagnum bogs with suppressed pine - raised bogs, and low-lying sedge-reed bogs with suppressed birch - swamp-subor. Low-lying sedge-reed bogs and wet bushy meadows are common on flat surfaces of low terraces. Forb and grass meadows often with willows on meadow soils are used for hayfields and pastures. The height above sea level of the studied mowing-and-grazing landscapes is $59 \mathrm{~m}$.

\section{Results}

Until the end of the 90s, about 800 heads of cattle were kept at the Oseevskaya dairy farm of the Uporovsky district of the Tyumen region, of which 200 were dairy cows, 50 were heifers, 300 were replacement calves, 250 were bull calves. All livestock of the farm and the private sector grazed on 2 natural pastures (geographic coordinates: N56.1721 ${ }^{\circ} \mathrm{E}$ $66.0819^{\circ}, \mathrm{N} 56.1597^{\circ} \mathrm{E} 66.0528^{\circ}$ ), one cultivated $\left(\mathrm{N} 56.1644^{\circ} \mathrm{E} 66.1051^{\circ}\right.$ ), and by the end of the pasture period - on mowed hayfields (N56.1634 ${ }^{\circ}$ E 66.0738 ${ }^{\circ}$ (Fig. 1). 


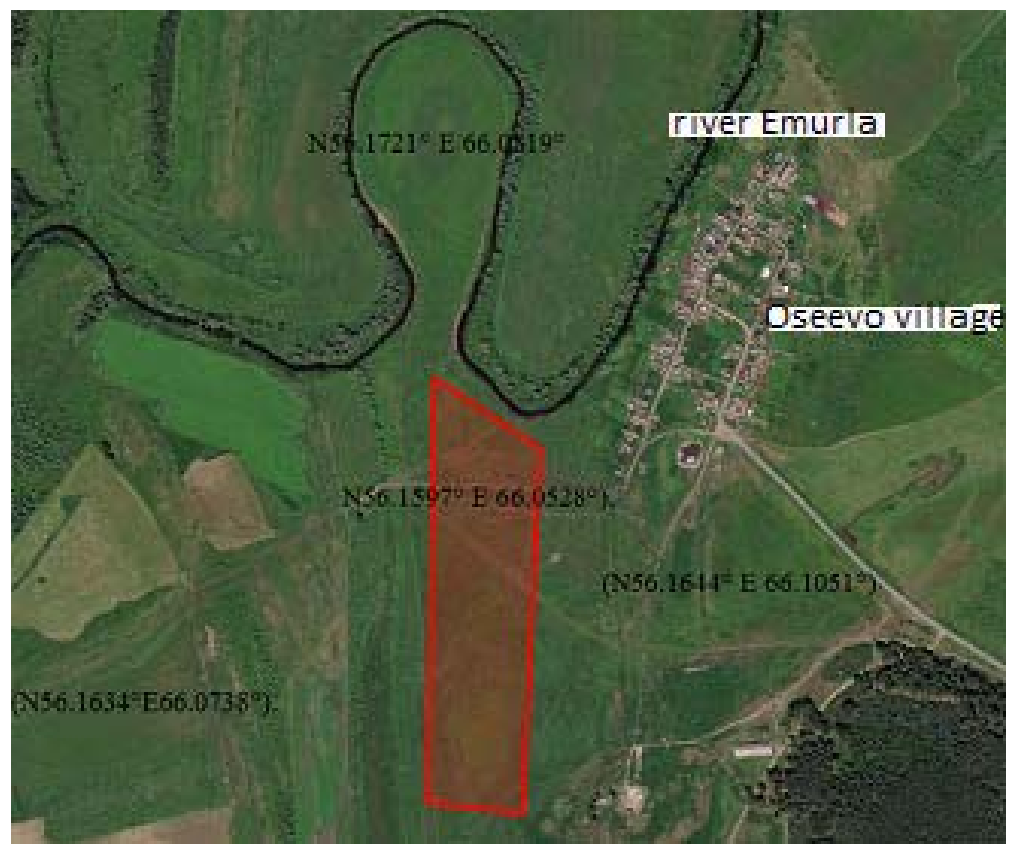

Fig. 1. Studied mowing-and-grazing landscapes http://russia-karts.ru/karta-tyumenskaja-oblastpodrobnaja-s-na.

The cultivated pasture was organized in the mid-60s of the last century by the method of surface improvement of low-productive natural pastures, which contained valuable species of forage grasses. At the same time, natural vegetation was completely preserved, with the exception of bushes. This is the simplest and cheapest way to increase the productivity of the land up to 3-4 thousand fodder units. On this pasture, the following cultural and technical measures were carried out: clearing from hummocks and shrubs of the Salix genus and drainage of stagnant water by canals into the Emurtla river, as a result of the leveled relief and poor surface runoff from the pasture. Taking into account that if the pasture is used improperly for 4 years, the number of inedible plants increases by $20-30 \%$, and the yield of forage grasses decreases by $40-50 \%$, pasture rotation in four turns was introduced on the pasture. Nowadays, part of the studied pasture area has undergone a secondary Salix succession, and Scots pine natural seed renewal is taking place in drier areas. Forests grow most rapidly where recently abandoned agricultural land coincides with favorable climatic conditions [6].

The remaining area of the meadow satisfies the need for grazing livestock of the private sector for pasture fodder, despite the fact that forest pastures were previously used along with these pastures, but as other studies confirm, the socialist and post-socialist era was characterized by the rejection of using the remnants of forest pasture land [7]. Taking into account that the typology of farms significantly affects the landscape [8], the grazing of animals in the individual sector is carried out with a load that does not exceed the permissible level.

The factors influencing the formation of phytocoenosis are very diverse and differ in individual climatic zones depending on the geographic location of the phytocoenosis [9].

The natural pastures of the studied area are actively used for haymaking. Over twenty years, in the absence of grazing livestock, the phytocoenosis of natural pastures has changed significantly, having gone through several stages [10], and began to play a key role in the formation of the soil fungal community. Even in the absence of grazing in the meadow, over time, there is a complete degeneration of good forage grasses, which are 
replaced by low-value and even fodder-harmful vegetation. This happens for a number of reasons. Meadow vegetation produces a large number of stems and shoots every year, and at the same time develops a powerful root system and a lot of rhizomes in the soil. The annually accumulating roots do not have time to rot, form a dense felt in the soil, and the sodding of the meadow begins. A layer of dead stems gradually accumulates on the surface of the soil. Free air access to the soil gradually slows down, the plant residues accumulating in it do not rot, easily absorb moisture, and form "acidic" humus that is harmful to plant life. This, in turn, leads to the disappearance of useful and valuable meadow grasses. Thus, if this meadow had not been hay-mowed by the private sector, its complete sodding and degeneration would have occurred, despite the fact that land without tillage has better soil aggregation and porosity [11].

Studies have shown that the plant community of the studied meadow contains the bush grass Calamagrostis epigejos (L.) Roth of the Bluegrass (Grass) Poaceae family and makes up $79 \%$ of the entire hayfield flora (Table 1). The herbage also contains mesophilic grasses - awnless brome grass Bromopsis inermis Leyss, meadow fescue grass Festuca pratensis $H u d s$, which are widespread in regions with a temperate climate and conditions of moderate moisture. Forage grasses of the Legume family (Fabaceae) are represented by hairy vetch Vicia villosa Roth, red clover Trifolium rubens $L$. and yellow alfalfa Medicago falcata $L$. Abiotic filters associated with low water availability and harsh microclimate conditions (high illumination, temperature and evaporation requirements), prevailing at the beginning of succession, correspond mainly to drought-resistant legumes [12].

Table 1. Plant modification of reed grass stand.

\begin{tabular}{|c|c|c|c|c|c|}
\hline No. & Plant name & Latin name & $\begin{array}{l}\text { Abundance } \\
\text { of species * }\end{array}$ & Value** & $\begin{array}{c}\text { Eatability } \\
* * *\end{array}$ \\
\hline 1. & Hairy vetch & Vicia villosa Roth & $\mathrm{sp}$ & $\mathrm{F}, \mathrm{B}$ & 4 \\
\hline 2. & Bush grass & $\begin{array}{l}\text { Calamagrostis epigejos } \\
\text { (L.) Roth }\end{array}$ & cop3 & $\mathrm{F}$ & 3 \\
\hline 3. & $\begin{array}{l}\text { Hedge } \\
\text { bedstraw }\end{array}$ & Galium mollugo L. & $\mathrm{sp}$ & $\mathrm{M}, \mathrm{F}$ & 2 \\
\hline 4. & Yellow alfalfa & Medicago falcata $L$. & cop1 & $\mathrm{F}, \mathrm{B}$ & 5 \\
\hline 5. & $\begin{array}{l}\text { Meadow } \\
\text { fescue grass }\end{array}$ & Festuca pratensis Huds & cop2 & $\mathrm{F}$ & 5 \\
\hline 6. & $\begin{array}{l}\text { Awnless } \\
\text { brome grass }\end{array}$ & $\begin{array}{l}\text { Bromopsis inermis } \\
\text { Leyss. }\end{array}$ & cop2 & $\mathrm{F}$ & 4 \\
\hline 7. & $\begin{array}{l}\text { Artemisia } \\
\text { austriaca }\end{array}$ & $\begin{array}{l}\text { Artemisia austriaca } \\
\text { Jacq. }\end{array}$ & $\mathrm{sp}$ & W & $0-1$ \\
\hline 8. & $\begin{array}{l}\text { Yellow } \\
\text { toadflax }\end{array}$ & Linaria vulgaris Mill. & cop1 & W, P & 1 \\
\hline 9. & $\begin{array}{l}\text { Reed canary } \\
\text { grass }\end{array}$ & $\begin{array}{l}\text { Phalaris } \\
\text { arundinacea L. }\end{array}$ & cop2 & $\mathrm{F}$ & 3 \\
\hline 10. & $\begin{array}{l}\text { Common } \\
\text { tansy }\end{array}$ & Tanacetum vulgare $L$. & sol & M & 0 \\
\hline 11. & Red clover & Trifolium rubens L. & cop1 & $\mathrm{F}, \mathrm{B}$ & 5 \\
\hline 12. & $\begin{array}{l}\text { Common } \\
\text { yarrow }\end{array}$ & Achillea millefolium $L$. & sol & M & 0 \\
\hline
\end{tabular}

* Abundance of species according to O. Drude scale.

** Qualitative assessment: $\mathrm{W}$ - weed, $\mathrm{F}$ - forage, $\mathrm{M}$ - medicinal, $\mathrm{P}$ - poisonous, $\mathrm{B}$ - bee plant

*** Eaten by animals on a 6-point system: 5 - excellent, 4 - good, 3 - satisfactory, 2 - below satisfactory, 1 - poor, 0 - not eaten.

In 2020, from an area of 12.25 hectares (highlighted in Fig. 1), with the amount of precipitation in May and June in the amount of 103 and 78\%, respectively, the yield of hay 
was 180 centners (14.7 centners/ha). This yield corresponds to natural meadows on meadow soils without cultivation.

Further succession of the meadow, as well as the quality of harvested hay, largely depends on the timing of mowing the grass. It would seem that late mowing, firstly, increases the amount of hay, since the grasses reach a significant size and, secondly, the ripe grasses seed the meadow. However, when the grass begins to bloom, the valuable nutrients contained in its stems and leaves gradually go to the formation of flowers, and then seeds. As a result, as the seeds ripen, the stems and leaves become more and more empty, coarse, the hay turns out to be strawy, difficult for animals to digest.

How much the quality of hay changes with the delay in harvesting is confirmed by the data in Table 2.

Table 2. Feed quality depending on the phenological phase of the grasses.

\begin{tabular}{|l|c|c|}
\hline \multicolumn{1}{|c|}{ Phenological phase } & Crude protein, \% & Crude fiber, \% \\
\hline Before flowering & 14.1 & 22.9 \\
\hline Flowering & 13.1 & 34.8 \\
\hline Ripening of seeds & 10.4 & 38.1 \\
\hline
\end{tabular}

In this regard, the recommended time for mowing is a week before flowering or the beginning of flowering of meadow grasses. Lagging with the harvesting of grasses, conditions for the seeding of meadows with weeds and grasses harmful to forage are created due to their high fertility and preservation of germination.

\section{Discussion}

Despite the fact that the decrease in fertility is not so noticeable on meadow soils, from year to year, the hayfields degenerate if they are not fertilized and if valuable forage grasses are not sown. The analysis of plant modification showed that the bulk of the crop is obtained from forbs. Therefore, the introduction of potash fertilizers will increase the content of grass family in the herbage and reduce the share of forbs. The introduction of nitrogen fertilizer in a mixture with potash and complete mineral fertilization reduces the content of forbs by almost half. A significant increase in yield and quality of forage is achieved by undersowing leguminous grasses to natural herbage. Research conducted by the Research Institute of the Northern Trans-Urals showed that after sowing red clover to the grass and forb herbage and applying all-nutrient fertilizer $\left(\mathrm{N}_{60} \mathrm{P}_{30} \mathrm{~K}_{60}\right)$, the hay increase was $165 \%$.

\section{References}

1. N.G. Lapenko, L.O. Ohanyan, Agrar. vestn. Urala, 9-17 (2019) DOI 10.32417/article_5dcd861t318036.10746233.

2. G. Quaranta, R. Salvia, L. Salvati, V. Imbrenda, T. Simoniello, Land Degradation and Development 31(16), 2379-2394 (2020)

3. G. Lebbink, J.M. Dwyer, R.J. Fensham, Ecological Management and Restoration 22(1), 5-9 (2021)

4. D. Sienkiewicz-Paderewska, J. Paderewski, I. Suwara, W. Kwasowski, Global Ecology and Conservation 23, e01188 (2020)

5. A.S. Motorin, A.V. Bukin, A.V. Iglovikov, IOP Conference Series: Earth and Environmental Science 90(1) (2017) doi:10.1088/1755-1315/90/1/012053

6. M. Garbarino, D. Morresi, C. Urbinati, A. Vitali, P.J. Weisberg, Landscape Ecology 35(12), 2679-2694(2020) 
7. M. Forejt, J. Skalos, A. Pereponova, T. Plieninger, J. Vojta, M. Šantrůčková, Applied Geography 79, 235-244 (2017)

8. N. Boke Olén, F. Roger, M.V. Brady, J. Dänhardt, Y. Clough, Agricultural Systems 189, 103071 (2021)

9. N.P. Nesgovorova, V.G. Savelev, G.V. Ivantsova, A.A. Purtova, M.G. Ufimtseva, International Scientific and Practical Conference "AgroSMART - Smart Solutions for Agriculture", "KnE Life Sciences", 1065-1077 (2019)

10. Shuaifeng Li, Xiaobo Huang, Jiayan Shen, Fandi Xu, Jianrong Su, Geoderma 379, $114646(2020)$

11. M. Flavio da Silva, M. Monique Honorato Fernandes, C. Fernandes, A. Manduca Rosa da Silva, A. Sérgio Ferraudo, A. Prates Coelho, Soil and Tillage Research 209, 104924 (2021)

12. M. Martínez-Ramos, F. Barragán, F. Mora, S. Maza-Villalobos, L.F. Arreola-Villa, R. Bhaskar, F. Bongers, C. Lemus-Herrera, H. Paz, A. Martínez-Yrizar, B.A. Santini, P. Balvanera, Forest Ecology and Management 482, 118810 (2021) 